\title{
A Biochemical Explanation for Lipid Accumulation in Candida 107 and Other Oleaginous Micro-organisms
}

\author{
By PHILIP A. BOTHAM AND COLIN RATLEDGE \\ Department of Biochemistry, University of Hull, Hull HU6 7RX
}

(Received 11 January 1979)

\begin{abstract}
The biochemical explanation for lipid accumulation was investigated principally in Candida 107 and, for comparison, in the non-oleaginous yeast Candida utilis. There were no significant differences between these two yeasts in their control of glucose uptake; in both yeasts, the rates of glucose uptake were independent of the growth rate and were higher in carbon-limited chemostat cultures than in nitrogen-limited cultures. There was no lipid turnover in either yeast, as judged from $\left[{ }^{14} \mathrm{C}\right]$ acetate uptake and subsequent loss of ${ }^{14} \mathrm{C}$ from the lipid of steady-state chemostat cultures. Acetyl-CoA carboxylase from both yeasts was similar in most characteristics except that from Candida 107 was activated by citrate ( $40 \%$ activation at $1 \mathrm{~mm}$ ). The enzyme from Candida 107 was relatively unstable and, when isolated from nitrogen-limited (lipid-accumulating) cultures, was accompanied by a low molecular weight inhibitor.

The reason for lipid accumulation is attributed to the decrease in the intracellular concentration of AMP as cultures become depleted of nitrogen. As the $\mathrm{NAD}^{+}$-dependent isocitrate dehydrogenase of Candida 107, but not C. utilis, requires AMP for activity, the metabolism of citrate through the tricarboxylic acid cycle in the mitochondria becomes arrested. In Candida 107, but not in C. utilis, there is an active ATP:citrate lyase which converts the accumulating citrate, when it passes into the cytosol, into acetyl-CoA and oxaloacetate. The former product is then available for fatty acid biosynthesis which is stimulated by the high ATP concentration within the cells, by the activation of acetyl-CoA carboxylase by citrate and by the provision of NADPH generated as oxaloacetate is converted via malate to pyruvate.

Similar characteristics were evident in oleaginous strains of Rhodotorula glutinis and Mucor circinelloides but not in non-oleaginous representatives of these species.
\end{abstract}

\section{INTRODUCTION}

Several species of yeast and a larger number of moulds can accumulate up to $70 \%$ of their biomass as lipid (Rattray et al., 1975; Ratledge, 1978) when grown with an excess of carbon and a deficit of nitrogen. Under such conditions, in both batch and continuous culture, protein and nucleic acid synthesis become curtailed but lipid synthesis continues at an undiminished rate and thus lipid builds up with respect to the remaining biomass (Kessell, 1968; Gill et al., 1977). Non-oleaginous organisms under the same growth conditions do not accumulate lipid. For example, Candida utilis does not accumulate more than 7 or $8 \%$ of its biomass as lipid even under the most propitious growth conditions (Babij et al., 1969; Thorpe \& Ratledge, 1972).

We have investigated the biochemical mechanisms behind this process, examining each of the following propositions as possible contributing causes.

1. Glucose uptake may continue unchecked into cells when nitrogen limits growth. The 
subsequent metabolism of glucose obliges the organism to find a suitable means of accommodating the surplus carbon as well as the energy, generated by respiration, and NADPH arising from the pentose phosphate cycle.

2. Acetyl-CoA carboxylase, the probable regulatory enzyme of fatty acid biosynthesis (White \& Klein, 1965, 1966; Gill \& Ratledge, 1973b; Volpe \& Vagelos, 1976), may be either hyper-active or not repressed or not subject to feedback inhibition when the organism enters a lipid-accumulating condition.

3. Lipid turnover may be negligible in an oleaginous organism so that what is synthesized is kept, whereas in a non-oleaginous yeast lipid turnover may occur at all times.

4. Intermediary metabolism may be regulated by the prevailing concentrations of adenine nucleotides within the cell (i.e. energy charge) which must change according to the prevailing growth condition (Atkinson, 1977; Chapman \& Atkinson, 1977; Knowles, 1977). In an oleaginous organism, this change would lead, in some way, to an undiminished or even increased flow of carbon from glucose into lipid. In a non-oleaginous organism, the energy charge of cells entering a carbon-excess growth situation would lead to a repression of the flow of carbon into lipid.

We realized at the outset of our work that the above four proposals would, to some extent, all have to be satisfied to explain oleaginicity and, moreover, that further conditions may have to be met to explain the phenomenon in full detail.

Before we commenced these studies, we examined the pathways of glucose metabolism in our model oleaginous yeast, Candida 107, as there had been a previous suggestion that in this yeast, as well as in the oleaginous yeast Rhodotorula glutinis, there was no phosphofructokinase and thus no Embden-Meyerhof pathway (Whitworth \& Ratledge, 1975; Höfer et al., 1969). However, we did find an active, though extremely labile, phosphofructokinase in both these yeasts and, from isotope-labelling studies with Candida 107, calculated that about $65 \%$ of the glucose as growth substrate was being metabolized via the pentose phosphate cycle, with the remainder going through the Embden-Meyerhof pathway (Ratledge \& Botham, 1977). In both yeasts, these two pathways of glucose dissimilation were augmented to an unknown extent by hexose- and pentose-phosphoketolase(s) (Whitworth \& Ratledge, 1977) which would serve to produce acetyl-CoA directly from glucose in the cytoplasm rather than in the mitochondria as usually happens.

It is our opinion, however, that the unusual occurrence of the phosphoketolases is insufficient to account for oleaginicity and that the metabolic reasons for it must lie in one or more of the above four propositions. The results of our study are presented here together with our hypothesis as to how lipid is accumulated in Candida 107 and in other oleaginous micro-organisms. A brief report of some of the early parts of this work has already appeared (Botham \& Ratledge, 1978).

\section{METHODS}

Organisms and growth. Candida 107, C. utilis NCYC 359, Rhodotorula glutinis strains NCYC 154G and NCYC 61, and Mucor circinelloides strains CMI 31800 and CMI 55452 were grown in medium containing $\left(\mathrm{g}^{-1}\right.$ ): glucose, $20 ; \mathrm{NH}_{4} \mathrm{Cl}, 0 \cdot 5 ; \mathrm{KH}_{2} \mathrm{PO}_{4}, 7 ; \mathrm{Na}_{2} \mathrm{HPO}_{4}, 2 ; \mathrm{MgSO}_{4} .7 \mathrm{H}_{2} \mathrm{O}, 1 \cdot 5 ;$ yeast extract, $1 \cdot 5 ; \mathrm{CaCl}_{2} .6 \mathrm{H}_{2} \mathrm{O}$, $0 \cdot 1 ; \mathrm{FeCl}_{3} .6 \mathrm{H}_{2} \mathrm{O}, 0.01$; and $\mathrm{ZnSO}_{4} .7 \mathrm{H}_{2} \mathrm{O}, 0.001$, for nitrogen-limited growth or in the same basal medium with glucose at $10 \mathrm{~g} \mathrm{l}^{-1}$ and $\mathrm{NH}_{4} \mathrm{Cl}$ at $1.5 \mathrm{~g} \mathrm{l}^{-1}$ for carbon-limited growth. Cultures were grown at $30^{\circ} \mathrm{C}$ either continuously in 21 or 51 chemostats or as batch cultures (without pH control or forced aeration) in $250 \mathrm{ml}$ shake-flasks or, occasionally, in vortex-aerated vessels. In fermenters, $\mathrm{pH}$ was controlled at $6 \cdot 0$ and aeration was at 1 vol. air per fermenter vol. $\mathrm{min}^{-1}$. Full details of medium sterilization and chemostat fermenter design and operation are given in Gill et al. (1977). Growth was followed turbidimetrically as $A_{600}$ which was then correlated to cell dry weights. The lipid content of cells was determined as previously described (Gill et al., 1977).

Preparation of cell suspensions and cell-free extracts. Cultures were harvested by centrifuging at $10000 \mathrm{~g}$ for 5 min and then washed in $0 \cdot 05 \mathrm{M}-\mathrm{KH}_{2} \mathrm{PO}_{4} / \mathrm{Na}_{2} \mathrm{HPO}_{4}$ buffer, pH 7.0, and re-centrifuged as before. For glucose transport assays, cells were then resuspended in the same buffer. 
For enzyme assays, cell extracts were prepared by ultrasonic disruption $(3 \times 20 \mathrm{~s}$ at $5 \mathrm{~A})$ of organisms. However, such extracts had low activities when assayed for acetyl-CoA carboxylase. The activity of this enzyme was increased considerably by first treating organisms with toluene (Serrano et al., 1973; Ratledge \& Botham, $1977)$ and then subjecting the lysed preparation to ultrasound $(3 \times 20 \mathrm{~s}$ at $5 \mathrm{~A})$. All acetyl-CoA carboxylase activities were assayed using extracts prepared by this modified method.

Disrupted cells were centrifuged at $4{ }^{\circ} \mathrm{C}$ at $40000 \mathrm{~g}$ for $30 \mathrm{~min}$, the supernatant was filtered through Whatman no. 1 filter paper to remove any solidified fat and the filtrate was stored on ice. Protein was determined by the biuret method (Gornall et al., 1949).

Glucose transport. A suspension of yeast $\left(7 \mathrm{ml}\right.$; between 0.5 and $\left.25 \mathrm{mg} \mathrm{dry} \mathrm{wt} \mathrm{ml}^{-1}\right)$ was incubated at $30{ }^{\circ} \mathrm{C}$ for about $5 \mathrm{~min} ; 2 \mathrm{ml} 5 \mathrm{mM}-\left[\mathrm{U}-{ }^{14} \mathrm{C}\right]$ glucose $\left(0.4 \mu \mathrm{Ci} \mu \mathrm{mol}^{-1}\right)$ was then added and incubation was continued with shaking. Samples $(0.5 \mathrm{ml})$ were withdrawn periodically and added immediately to $3 \mathrm{ml} 0.05 \mathrm{M}-$ $\mathrm{KH}_{2} \mathrm{PO}_{4} / \mathrm{Na}_{2} \mathrm{HPO}_{4}$ buffer, pH 7.0, being held on a glass-fibre filter (Whatman grade A). Suction was applied immediately and the cells on the filter were washed twice with $3 \mathrm{ml}$ buffer. The filter paper was transferred to $10 \mathrm{ml}$ dioxan-based scintillation fluid (see below) for determination of radioactivity. Time courses for glucose uptake over about $20 \mathrm{~min}$ were plotted and initial rates of uptake then calculated.

Enzyme assays. Acetyl-CoA carboxylase (EC 6.4.1.2; acetyl-CoA:carbon-dioxide ligase (ADP-forming)]. Initially the assay system of Matsuhashi (1969), which measures the incorporation of label from $\left[1-{ }^{14} \mathrm{C}\right]$ acetylCoA into saponifiable lipid, and the assay system of Inoue \& Lowenstein (1975), which follows the incorporation of ${ }^{14} \mathrm{CO}_{2}$ from $\mathrm{NaH}^{14} \mathrm{CO}_{3}$ into acid-stable material (which includes malonyl-CoA), were used. Both gave low values for the activity of the enzyme in cell-free extracts, but a method using ultrasonically disrupted toluene-lysed cells gave considerably higher activities. The assay mixture contained (in $1 \mathrm{ml}$ ) $175 \mu \mathrm{mol}$ Tris $/ \mathrm{HCl}$ buffer, pH 7.5, 2.0 $\mu \mathrm{mol} \mathrm{MgCl}_{2}, 1.0 \mu \mathrm{mol}$ dithiothreitol, $15 \mu \mathrm{mol}$ ATP, $10 \mu \mathrm{mol} \mathrm{NaHCO}, 2 \mu \mathrm{mol}$ CoASH, $2 \mu \mathrm{mol}$ glucose 6-phosphate, $0.5 \mu \mathrm{mol} \mathrm{NADP}{ }^{+}, 1$ unit of glucose-6-phosphate dehydrogenase and $2.5 \mu \mathrm{mol}\left[1{ }^{14} \mathrm{C}\right]$ acetate $(0.5 \mu \mathrm{Ci})$ for assays with Candida 107 or $10 \mu \mathrm{mol}\left[1-{ }^{14} \mathrm{C}\right]$ acetate $(2 \cdot 0 \mu \mathrm{Ci})$ for assays with $C$. utilis; $0.5 \mathrm{ml}$ cell-free extract prepared from toluene-lysed cells (see above) was added to start the reaction. After $5 \mathrm{~min}$ at $30^{\circ} \mathrm{C}$ with shaking, the reaction mixture was placed in liquid nitrogen $\left(-195^{\circ} \mathrm{C}\right)$ and then freeze-dried. Lipid was extracted by overnight stirring of the lyophilized material in $40 \mathrm{ml}$ chloroform/methanol $(2: 1, \mathrm{v} / \mathrm{v})$. The extract was washed with $40 \mathrm{ml} 1 \%(\mathrm{w} / \mathrm{v}) \mathrm{NaCl}$, twice with distilled water and dried over anhydrous $\mathrm{MgSO}_{4}$ before being filtered and evaporated under reduced pressure. The lipid residue was taken up in $1 \mathrm{ml}$ toluene and radioactivity was counted in a liquid scintillation spectrometer. On occasions, $4 \mu \mathrm{mol}\left[1{ }^{14} \mathrm{C}\right]$ acetyl-CoA $(0.6 \mu \mathrm{Ci})$ was substituted for $\left[1-{ }^{14} \mathrm{C}\right]$ acetate to ensure the activity detected by the assay was not limited by the activity of acetyl-CoA synthetase. [1-14 C]Acetyl-CoA was prepared from $\left[1{ }^{14} \mathrm{C}\right]$ acetic anhydride by the method of Simon \& Shemin (1953). Enzyme activities are expressed as rates of incorporation of acetate (or acetyl-CoA) into lipid.

Acetate kinase [EC 2.7.2.1; ATP:acetate phosphotransferase] and phosphate acetyltransferase [EC 2.3.1.8; acetyl-CoA:orthophosphate acetyltransferase] were assayed by the procedures given previcusly (Ratledge \& Botham, 1977). For both enzymes, activities are expressed as rates of product formation.

Acetyl-CoA synthetase [EC 6.2.1.1; acetate: CoA ligase (AMP-forming)] was assayed by a method based on that of Webster (1969) in which the production of acetyl-CoA during 5 min incubation at $30^{\circ} \mathrm{C}$ was measured by conversion to the ferric acetohydroxamate.

$\mathrm{NAD}^{+}$-dependent isocitrate dehydrogenase [EC 1.1.1.41; threo- $\mathrm{D}_{\mathrm{s}}$-isocitrate: $\mathrm{NAD}^{+}$oxidoreductase (decarboxylating)] was assayed by the method of Kornberg (1955) by measuring $\Delta A_{340}$ due to reduction of $\mathrm{NAD}^{+}$.

ATP-citrate lyase [EC 4.1.3.8; ATP: citrate oxaloacetate-lyase] was assayed by the procedure of Srere (1962), in which the oxaloacetate formed is reduced to malate by the action of malate dehydrogenase, by following $\Delta A_{340}$ due to oxidation of NADH.

Aconitase [EC 4.2.1.3; citrate(isocitrate) hydro-lyase] was assayed by the method of Anfinsen (1955) by following $\Delta A_{240}$ due to formation of cis-aconitate.

Lipid turnover. Candida 107 and $C$. utilis were grown in nitrogen-limited medium in chemostats at a dilution rate of $0.05 \mathrm{~h}^{-1}$. Sodium $\left[1{ }^{14} \mathrm{C}\right]$ acetate $\left(125 \mu \mathrm{Ci}, 60 \mu \mathrm{Ci} \mu \mathrm{mol}^{-1}\right)$ was injected by syringe into the chemostat. At intervals, samples $(5 \mathrm{ml})$ were removed, filtered with suction through glass-fibre paper (Whatman grade $\mathrm{A}$ ) and the cells on the filter were washed with $5 \mathrm{ml} 0.05 \mathrm{M}-\mathrm{KH}_{2} \mathrm{PO}_{4} / \mathrm{Na}_{2} \mathrm{HPO}_{4}$ buffer, pH $7 \cdot 0$, before being freeze-dried.

Radioactivity in the filtrate was counted in a dioxan-based scintillation fluid (see below). Lipid in the cells was extracted by the method described under the assay of acetyl-CoA carboxylase. The lipid residue was re-dissolved in chloroform and a sample was taken for scintillation counting. The remainder, after weighing following evaporation of the solvents, was fractionated by chromatography on a column of silicic acid by the method described by Rouser et al. (1967) (see also Gill et al., 1977) to give neutral lipids, glycolipids and phospholipids. Radioactivity in all lipid fractions was measured by liquid scintillation counting in a toluenebased scintillation fluid (see below). 
Adenine nucleotide concentrations. Chemostats were fitted, through the top plate, with a long (300 $\mathrm{mm})$ hypodermic needle attached to a three-way tap. When samples were required, a $20 \mathrm{ml}$ syringe, containing $4 \mathrm{ml} 1.5 \mathrm{M}_{-} \mathrm{H}_{2} \mathrm{SO}_{4}$, was attached to the needle and a vacuum was created in the syringe by pulling back the plunger with the tap in an appropriate position. Rapid withdrawal of culture fluid $(16 \mathrm{ml})$, with concomitant rapid quenching of enzyme activity by the acid, was obtained when the position of the tap was switched. After sampling, the tap was returned to its previous position and the syringe could be removed without danger of contaminating the remaining culture. Quenching of samples was estimated to take no longer than $1 \mathrm{~s}$. Knowles (1977) has estimated that this method gives a quenching time of a few milliseconds.

The quenched sample was diluted 1 in 10 with $5 \mathrm{mM}-\mathrm{KH}_{2} \mathrm{PO}_{4} / \mathrm{Na}_{2} \mathrm{HPO}_{4}$ buffer, pH 7.3. To $10 \mathrm{ml}$ of the diluted sample was added $10 \mathrm{ml}$ of the same buffer containing ATP, ADP and AMP each at $1 \mu \mathrm{M}$. This sample and a control sample containing only additional buffer were then neutralized to $\mathrm{pH} 7 \cdot 3 \mathrm{with} 1 \mathrm{M}$ $\mathrm{NaOH}$. Cell debris was removed by centrifuging at $10000 \mathrm{~g}$ for $5 \mathrm{~min}$ and the supernatants were then further diluted 1 in 10 with the same buffer.

The adenine nucleotide concentrations were determined in both samples by the luciferin/luciferase method of Strehler \& McElroy (1957) as modified by Chapman et al. (1971), which measures ADP and AMP by their conversion to ATP and ADP, respectively. ATP was estimated in an ATP instrument (EMI, type 6097S; Dawes \& Large, 1970) by the bioluminescence produced on addition of luciferin/luciferase in the form of an extract of firefly lanterns. The luciferase assay consisted of $1 \mathrm{ml} \mathrm{MgSO} 4 \cdot 7 \mathrm{H}_{2} \mathrm{O}\left(1 \cdot 5 \mathrm{mg} \mathrm{ml}^{-1}\right), 1 \mathrm{ml}$ water and $1 \mathrm{ml}$ incubation mixture contained within a plastic vial. At zero time, $0 \cdot 1 \mathrm{ml}$ lantern extract was added and the bioluminescence was measured as a deflection on a pen recorder. The deflection after $15 \mathrm{~s}$ was taken as being proportional to the concentration of ATP present. Deflections from AMP and ADP assay mixtures were corrected for the secondary bioluminescence due to AMP and ADP in the lantern extract.

Firefly lantern extract (FLE-250; Sigma) was prepared in distilled water to give $18 \mathrm{mg} \mathrm{ml}^{-1}$; extracts thus prepared contained luciferin/luciferase in arsenate/sulphate buffer, $\mathrm{pH} 7 \cdot 3$. Assays were performed in triplicate, with less than $\pm 1 \%$ variation, and the deflections due to converted AMP and ADP were determined by difference. Concentrations of nucleotides were calculated from appropriate reference standards including those of the internal control.

Radioactive counting by liquid scintillation. Lipid samples were usually dissolved in toluene (1 ml) and added to $10 \mathrm{ml}$ of a solution of $4 \mathrm{~g} \mathrm{2,5-diphenyloxazole} \mathrm{in} 11$ toluene. Aqueous samples (1 ml) were counted in $10 \mathrm{ml}$ of a solution of $4 \mathrm{~g}$ 2,5-diphenyloxazole, $60 \mathrm{~g}$ naphthalene, $20 \mathrm{ml}$ ethanediol, $100 \mathrm{ml}$ methanol and $880 \mathrm{ml}$ dioxan. Appropriate controls were also counted to give corrections for counting efficiencies.

\section{RESULTS AND DISCUSSION}

The four main postulates considered as reasons for lipid accumulation (see Introduction) were investigated in Candida 107 and Candida utilis; the latter usually accumulates no more than $7 \%$ of its biomass as lipid (Babij et al., 1969; Thorpe \& Ratledge, 1972).

\section{Regulation of glucose transport}

Glucose transport in Candida 107 and other yeasts occurs by an active process which is tightly coupled to energy metabolism (Gill \& Ratledge, 1973a) and thus could be under metabolic control. Although glucose must continue to be taken up by an oleaginous yeast which has entered a nitrogen-limited phase of growth, glucose transport in a non-oleaginous yeast may be repressed or inhibited.

The rate of uptake of $\left[\mathrm{U}^{14} \mathrm{C}\right]$ glucose into washed suspensions of Candida 107, grown in continuous culture at a dilution rate of $0.05 \mathrm{~h}^{-1}$ in nitrogen-limited medium to give the highest content of lipid, was only twice that of $C$. utilis grown under the same conditions, although there was a 10 -fold difference in the lipid contents of these two yeasts (Table 1). The rate of transport of glucose in Candida 107 was always substantially higher than that in C. utilis under nitrogen-limited conditions even though the lipid contents were similar at the fastest growth rates. Under carbon-limited conditions, the glucose transport ability of both yeasts increased to about the same activity, presumably to increase the yeasts' capacity for scavenging the growth substrate.

The rates of uptake under both nitrogen- and carbon-limitation did not vary proportionately with changes in the growth rate suggesting that glucose transport is not the growthlimiting step in either yeast. This is consistent with the conclusions of Neijssel et al. (1977) 
Table 1. Rates of uptake of $\left[U^{14} C\right]$ glucose into washed suspensions of Candida 107 and Candida utilis grown in continuous culture

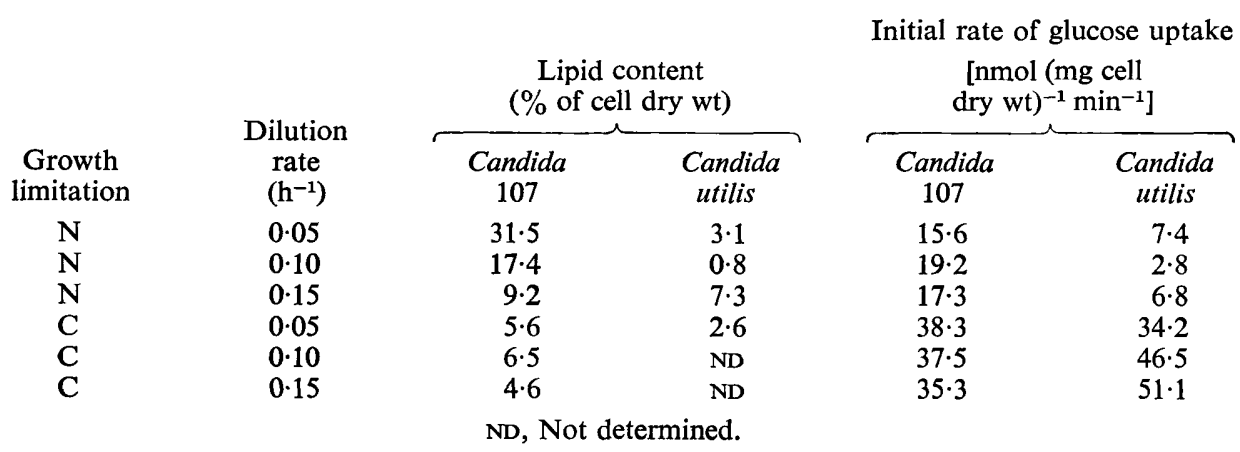

who found that in Escherichia coli, Klebsiella aerogenes and Bacillus subtilis as well as in C. utilis the capacity for glucose transport was greater than was needed when these organisms were grown in glucose-limited chemostat cultures. Hence, the rate at which cells take up glucose does not limit their rate of growth nor can it be the means of regulating lipid synthesis in oleaginous or non-oleaginous yeasts.

\section{Acetyl-CoA carboxylase}

Activities of acetyl-CoA carboxylase varied from 60 to $160 \mathrm{nmol} \mathrm{h}^{-1}\left(\mathrm{mg}\right.$ protein) ${ }^{-1}$ in both Candida 107 and C. utilis. The activity was dependent on ATP, CoASH and $\mathrm{NaHCO}_{3}$ and was similar whether $\left[1-{ }^{14} \mathrm{C}\right]$ acetate or $\left[1-{ }^{14} \mathrm{C}\right]$ acetyl-CoA was the substrate. The incorporation of radioactivity from $\left[1-{ }^{14} \mathrm{C}\right]$ acetate was a measure of acetyl-CoA carboxylase and was not limited by the activity of acetyl-CoA synthetase which, being about $1.0 \mu \mathrm{mol} \mathrm{h}^{-1}$ (mg protein $)^{-1}$ in both yeasts, was an order of magnitude higher than the activity of acetylCoA carboxylase. [Although there was a low activity of acetate kinase in both yeasts, there was no activity of phosphate acetyltransferase (see Ratledge \& Botham, 1977) indicating that synthesis of acetyl-CoA was solely via acetyl-CoA synthetase.] The $K_{\mathrm{m}}$ values for acetyl-CoA, calculated in the usual manner, were $4 \mathrm{~mm}$ in Candida 107 and $3 \mathrm{~mm}$ in C. utilis. The $K_{\mathrm{m}}$ for ATP was high in both yeasts: $7 \mathrm{~mm}$ in Candida 107 and $15 \mathrm{~mm}$ in C. utilis.

Of various effectors, citrate up to $10 \mathrm{~mm}$ activated the enzyme in extracts of Candida 107 with a maximum stimulation (about $40 \%$ ) at $1 \mathrm{~mm}$, but the enzyme in C. utilis was not affected by this metabolite (Fig. $1 a$ ). Activation by citrate was not attributed to a stimulation of ATP: citrate lyase as this would produce unlabelled acetyl-CoA leading to a dilution of the label incorporated into the lipid.

Fructose 1,6-bisphosphate inhibited the enzyme in both yeasts (Fig. 1b); these results thus differed from the findings of Gill \& Ratledge (1973b) with Candida 107 and of White \& Klein $(1965,1966)$, Rasmussen \& Klein $(1967,1968)$ and Hayashi et al. (1978) with Saccharomyces cerevisiae where this effector enhanced the enzyme's activity. 2-Oxoglutarate, DLglycerol 3-phosphate, phosphoenolpyruvate (each up to $20 \mathrm{~mm}$ ) or stearoyl-CoA (up to $200 \mu \mathrm{M})$ did not affect the enzyme from either yeast. Gill \& Ratledge $(1973 b)$ had previously found that acetyl-CoA carboxylase was sensitive to feedback inhibition by stearoyl-CoA at $100 \mu \mathrm{M}$ and by palmitoyl-CoA at $200 \mu \mathrm{m}$. Clearly, there are differences in the response of the enzyme between the two series of experiments and purified preparations of acetylCoA carboxylase are probably needed to resolve the situation. The difference may be explained, at least in part, by the activities of acetyl-CoA carboxylase found by Gill \& Ratledge (1973b) being much lower than those reported here. The activities found in the present experiments are approximately what one would expect from the probable rate of lipid synthesis in batch-cultivated cells. 

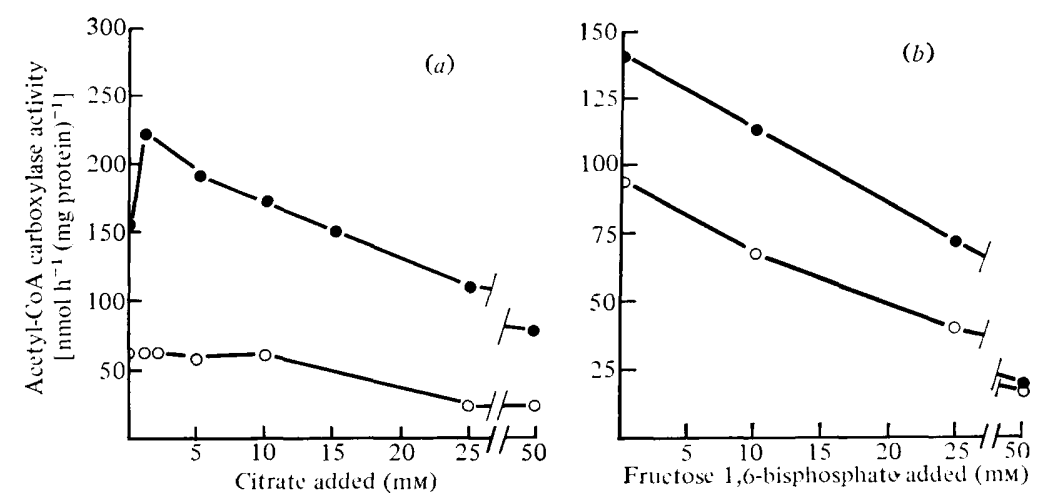

Fig. 1. Effect of citrate $(a)$ and fructose 1,6-bisphosphate $(b)$ on the specific activity of acetyl-CoA carboxylase in extracts of Candida 107 (O) and C. utilis (O) grown in nitrogen-limited batch cultures. Extracts were prepared by ultrasonic disruption of toluene-lysed cells (see Methods).

Attempts to obtain an active enzyme from cells grown in continuous culture, where for Candida 107 the specific rate of lipid synthesis is about $0.03 \mathrm{~g}$ lipid synthesized $\mathrm{h}^{-1}$ (g cell dry wt) $)^{-1}$ (Gill et al., 1977), gave very low activities when the cells were nitrogen-limited. Only in extracts from carbon-limited cells were active enzymes detected: in Candida 107, acetylCoA carboxylase activity was approx. $300 \mathrm{nmol} \mathrm{h}^{-1}(\mathrm{mg} \text { protein })^{-1}$ and in C. utilis approx. $900 \mathrm{nmol} \mathrm{h}^{-1}$ (mg protein) ${ }^{-1}$. Both these activities were similar to, or greater than, the calculated values from in vivo measurements of rates of lipid accumulation. The low activity of the enzyme in extracts from nitrogen-limited Candida 107 was attributed to a low molecular weight inhibitor (not a fatty acid or a fatty acyl-CoA ester) being released during cell disruption since a mixture of cell-free extracts from nitrogen-limited and carbonlimited cells still had a low activity.

The higher specific activity of acetyl-CoA carboxylase in Candida 107 than in C. utilis (see Fig. 1) is probably not enough to account for lipid accumulation unless it were accompanied by appropriate activation of the enzyme and a continuous supply of substrate and cofactors. The stimulatory effect of citrate on the enzyme from Candida 107 but not C. utilis is therefore probably significant.

\section{Lipid turnover}

The possibility that the rates of lipid turnover were different in the two yeasts was investigated by adding carrier-free sodium $\left[1-{ }^{14} \mathrm{C}\right]$ acetate $\left(125 \mu \mathrm{Ci}, 60 \mu \mathrm{Ci} \mu \mathrm{mol}^{-1}\right)$ to steadystate cultures of Candida 107 and $C$. utilis growing in nitrogen-limited medium (1.51) in a chemostat at a dilution rate of $0.05 \mathrm{~h}^{-1}$. The amounts of label remaining in the growth medium and incorporated into the total cell lipid and in the three main lipid fractions (neutral lipid, glycolipid and phospholipid) were determined during the subsequent $72 \mathrm{~h}$, during which time there were over three complete changes of medium through the fermenter.

In both yeasts, $97 \%$ of the $\left[1-{ }^{14} \mathrm{C}\right]$ acetate was taken up within $15 \mathrm{~min}$. In Candida 107, almost $50 \%$ of the labelled acetate entered the various lipid pools; in C. utilis, about $30 \%$ was so assimilated. Samples taken during the first $2 \mathrm{~h}$ gave variable values for the specific activities of the total lipid, possibly due to interchange of labelled material between various pools of acetate or acetyl-CoA within the cells, but thereafter the proportions stayed constant indicating a steady state had been reached.

The decline in the specific activity of the total lipid was at a constant exponential rate in both Candida 107 and C. utilis and was equal to the rate at which cells were lost from the chemostat. For Candida 107, the radioactivity declined from 60000 d.p.m. (mg total lipid) ${ }^{-1}$ at $4 \mathrm{~h}$ after pulse labelling to 2500 d.p.m. (mg total lipid) ${ }^{-1}$ after $62 \mathrm{~h}$; this gave an expo- 
nential loss corresponding to a dilution rate of $0.050 \mathrm{~h}^{-1}$ and the correlation coefficient of the data, involving a total of 10 samples, to an exponential curve was -0.998 . For C. utilis, the radioactivity declined from 130000 d.p.m. (mg total lipid) ${ }^{-1}$ at $2 \mathrm{~h}$ after pulse labelling to 2000 d.p.m. (mg total lipid) ${ }^{-1}$ after $72 \mathrm{~h}$; this gave an exponential rate of loss corresponding to a dilution rate of $0.054 \mathrm{~h}^{-1}$ with a correlation coefficient, involving 13 data points, of -0.978 to an exponential curve. An identical rate of decline occurred in the specific activity of the neutral lipid fraction in Candida 107 (correlation coefficient of the data to an exponential curve was -0.997 ). This fraction, which is principally triacylglycerol, accounted for about $80 \%$ of the total lipid in Candida 107 and is the principal form in which lipid is stored within an oleaginous yeast (Thorpe \& Ratledge, 1972; Uzuka et al., 1975). The amounts of glycolipid and phospholipid in Candida 107 and of all three lipid fractions in C. utilis were too small to enable accurate rates of loss to be determined, though in each case loss of label followed the same exponential decline seen for the total lipid. We conclude, therefore, that in both yeasts lipid turnover either does not occur or occurs at an immeasurably slow rate.

\section{Energy charge and the effects of adenine nucleotides on some key enzymes of intermediary metabolism}

The concentrations of various metabolites within cells growing under nitrogen-limitation are likely to differ from those in carbon-limited cells. Such differences will include variation in the intracellular concentrations of adenine nucleotides (Thomas \& Dawson, 1977) which would then have an effect on the activity of one or more regulatory enzymes involved in lipid biosynthesis (see Marchal et al., 1977; Mitsushima et al., 1978).

Energy charge. The total intracellular adenine nucleotide concentrations in nitrogen- and carbon-limited steady-state cultures of Candida 107 and C. utilis (Table 2) were significantly lower than those found by other workers. The ATP content of eukaryotic micro-organisms is generally between 2.4 and $8.9 \mathrm{nmol}\left(\mathrm{mg}\right.$ cell dry wt) ${ }^{-1}$ (Chapman \& Bartley, 1969; Knowles, 1977; Thomas \& Dawson, 1977), whereas in these studies it was between 0.5 to $2.5 \mathrm{nmol}$ (mg cell dry wt) ${ }^{-1}$. Similarly, the amount of AMP was higher than that normally found in yeast. Consequently, the computed energy charge (Atkinson, 1969) under both carbon- and nitrogen-limitation in both yeasts was low: the highest value was 0.57 in Candida 107 growing under nitrogen-limitation.

The growth rate did not affect the energy charge, except in C. utilis under carbonlimitation when the energy charge increased with decreasing growth rate. The effect of growth rate on adenylate energy charge has not been reported for yeast in continuous culture, but, in bacteria, ATP pools remain constant over a wide range of dilution rates (Harrison \& Maitra, 1969; Hobson \& Summers, 1972; Dolezal \& Kapralek, 1976).

These low values were not due to inadequate extraction of ATP by the quenching agent (1.5 $\mathrm{M}-\mathrm{H}_{2} \mathrm{SO}_{4}$ ), as re-acidification of the cell debris remaining after one acid treatment did not yield any further adenine nucleotides. Neither were the low energy charges due to the excretion of significant amounts of ATP or AMP into the growth medium (Table 2). The quenching time during sampling was estimated to be one second or less; hence significant changes in the intracellular adenine nucleotides due to enzyme action are unlikely.

If the intracellular water space of Candida 107 is between 2 and $4 \mu 1$ (mg cell dry wt) ${ }^{-1}$ (Knowles, 1977), then an average value for the intracellular concentration of AMP in Candida 107 growing under nitrogen-limitation is about 0.3 to $0.6 \mathrm{~mm}$ whereas under carbonlimitation it is about 1.9 to $3.8 \mathrm{~mm}$. In C.utilis, the respective values are between 0.9 and $1.8 \mathrm{~mm}$ and between 1.5 and $3.0 \mathrm{mM}$. The significantly lower concentration of AMP in Candida 107 under nitrogen-limitation led us to examine the effects of this nucleotide and also, where possible, combinations of nucleotides to create an 'in vitro' energy charge on certain key enzymes of intermediary metabolism.

Acetyl-CoA carboxylase. Acetyl-CoA carboxylase from Candida 107 was slightly activated by AMP up to $10 \mathrm{~mm}$, whereas in $C$. utilis the enzyme was only significantly inhibited if 
Table 2. Effect of nitrogen- and carbon-limitation and of growth rate on the intracellular and extracellular adenine nucleotide concentrations and the energy charge of Candida 107 and of Candida utilis

Cells were grown in continuous culture. Samples were taken by rapid sampling into $1 \cdot 5 \mathrm{M}-\mathrm{H}_{2} \mathrm{SO}_{4}$. Results are for one typical experiment of three which were carried out; the maximum variation between experiments for any determination was $\pm 6 \%$ and was normally much less than this.

\begin{tabular}{|c|c|c|c|c|c|c|c|c|c|}
\hline \multirow{3}{*}{$\begin{array}{l}\text { Organism } \\
\text { and } \\
\text { limiting } \\
\text { nutrient }\end{array}$} & \multirow{3}{*}{$\begin{array}{c}\text { Cell } \\
\text { dry wt } \\
\left(\mathrm{mg} \mathrm{ml}^{-1}\right)\end{array}$} & \multirow{3}{*}{$\begin{array}{l}\text { Dilution } \\
\text { rate } \\
\left(\mathrm{h}^{-1}\right)\end{array}$} & \multicolumn{6}{|c|}{ Adenine nucleotides [nmol ( $\mathrm{mg}$ cell dry wt) ${ }^{-1}$ ] } & \multirow{3}{*}{$\begin{array}{l}\text { Intra- } \\
\text { cellular } \\
\text { energy } \\
\text { charge* }\end{array}$} \\
\hline & & & \multicolumn{3}{|c|}{ Intracellular } & \multicolumn{3}{|c|}{ Extracellular } & \\
\hline & & & AMP & ADP & ATP & AMP & ADP & ATP & \\
\hline \multicolumn{10}{|c|}{ Candida 107} \\
\hline $\mathbf{N}$ & $8 \cdot 8$ & 0.050 & $1 \cdot 6$ & $4 \cdot 4$ & $2 \cdot 2$ & 0 & 0.9 & $0 \cdot 2$ & 0.54 \\
\hline$N$ & $6 \cdot 1$ & 0.085 & 0.5 & $8 \cdot 7$ & $1 \cdot 2$ & 0 & $1 \cdot 4$ & 0.4 & 0.53 \\
\hline $\mathbf{N}$ & $5 \cdot 6$ & $0 \cdot 115$ & 0.9 & $3 \cdot 7$ & 0.9 & 0 & $1 \cdot 4$ & 0.4 & 0.50 \\
\hline $\mathbf{N}$ & $4 \cdot 7$ & $0 \cdot 145$ & $1 \cdot 3$ & $4 \cdot 5$ & $2 \cdot 4$ & 0 & $2 \cdot 5$ & $0 \cdot 7$ & 0.57 \\
\hline $\mathbf{C}$ & $6 \cdot 2$ & 0.050 & $9 \cdot 0$ & $1 \cdot 4$ & $0 \cdot 5$ & 0 & $0 \cdot 4$ & $0 \cdot 2$ & $0 \cdot 11$ \\
\hline C & $6 \cdot 3$ & 0.085 & $9 \cdot 6$ & $1 \cdot 7$ & 0.5 & $0 \cdot 1$ & $1 \cdot 3$ & $0 \cdot 2$ & $0 \cdot 16$ \\
\hline $\mathrm{C}$ & $6 \cdot 0$ & $0 \cdot 115$ & $6 \cdot 0$ & $2 \cdot 0$ & 0.8 & $0 \cdot 1$ & 0.4 & $0 \cdot 1$ & $0 \cdot 20$ \\
\hline $\mathrm{C}$ & $5 \cdot 5$ & $0 \cdot 145$ & $6 \cdot 0$ & $1 \cdot 6$ & $0 \cdot 2$ & $0 \cdot 1$ & $0 \cdot 5$ & $0 \cdot 2$ & $0 \cdot 13$ \\
\hline \multicolumn{10}{|c|}{ Candida utilis } \\
\hline $\mathrm{N}$ & $6 \cdot 5$ & 0.050 & 3.5 & $2 \cdot 3$ & 0.7 & $0 \cdot 1$ & 0.4 & $0 \cdot 1$ & 0.28 \\
\hline $\mathbf{N}$ & $6 \cdot 7$ & 0.085 & $3 \cdot 8$ & $3 \cdot 4$ & 0.9 & $\mathbf{0}$ & $0 \cdot 3$ & 0 & $0 \cdot 32$ \\
\hline$N$ & $5 \cdot 8$ & $0 \cdot 115$ & $3 \cdot 7$ & $2 \cdot 8$ & 0.95 & 0 & $0 \cdot 3$ & 0.05 & 0.32 \\
\hline $\mathbf{N}$ & $5 \cdot 8$ & $0 \cdot 145$ & $3 \cdot 1$ & 1.9 & $0 \cdot 7$ & $0 \cdot 1$ & $0 \cdot 3$ & $0 \cdot 1$ & $0 \cdot 29$ \\
\hline C & $5 \cdot 8$ & 0.050 & 3.9 & $2 \cdot 8$ & $1 \cdot 6$ & $0 \cdot 2$ & 0.5 & $0 \cdot 1$ & $0 \cdot 36$ \\
\hline $\mathrm{C}$ & $5 \cdot 75$ & 0.085 & $6 \cdot 2$ & $2 \cdot 9$ & $1 \cdot 2$ & 0.2 & $0 \cdot 3$ & $0 \cdot 1$ & $0 \cdot 26$ \\
\hline $\mathrm{C}$ & $6 \cdot 0$ & $0 \cdot 115$ & $6 \cdot 55$ & $3 \cdot 0$ & $1 \cdot 2$ & $0 \cdot 15$ & 0.5 & $0 \cdot 1$ & 0.25 \\
\hline $\mathrm{C}$ & 6.0 & 0.145 & $7 \cdot 8$ & $2 \cdot 4$ & 0.55 & 0 & 0.4 & $0 \cdot 15$ & $0 \cdot 16$ \\
\hline
\end{tabular}

AMP was above $7 \cdot 5 \mathrm{~mm}$ (Fig. $2 a$ ). The effect of in vitro energy charges on this enzyme could not be ascertained because the assay mixture requires ATP to be present above its $K_{\mathrm{m}}$ value, which was high in both yeasts (see above). Very high (about $20 \mathrm{~mm}$ ) non-physiological concentrations of AMP would therefore be needed to give low in vitro energy charges.

With prevailing intracellular concentrations of adenine nucleotides, acetyl-CoA carboxylase would not be inhibited in either yeast during growth under either carbon- or nitrogen-limitation.

$N A D^{+-d e p e n d e n t ~ i s o c i t r a t e ~ d e h y d r o g e n a s e . ~ T h i s ~ e n z y m e, ~ w h i c h ~ i s ~ m i t o c h o n d r i a l ~ i n ~ o r i g i n, ~}$ has been widely reported to depend for its activity on allosteric activation by AMP (Kornberg \& Pricer, 1951; Hathaway \& Atkinson, 1963). Indeed, this enzyme catalyses one of the regulatory steps implicated in the Pasteur effect: when the energy charge is high, with a high ATP/AMP ratio, the metabolism of citrate slows down because of a decrease in the enzyme's activity (Sols et al., 1971). Accumulation of citrate in Candida lipolytica has been explained by allosteric inactivation of this enzyme due to a decrease in the intracellular (intramitochondrial?) AMP concentration during nitrogen-limited growth (Marchal et al., 1977; Mitsushima et al., 1978).

In extracts of both nitrogen- and carbon-limited cells of Candida 107, NAD+-dependent isocitrate dehydrogenase activity was almost completely absent when AMP was not added to the assay. Activity was stimulated up to 30 -fold by adding AMP as low as $0.5 \mathrm{~mm}$. No further significant stimulation occurred on increasing AMP to $5 \mathrm{mM}$ (Fig. $2 b$ ).

In extracts of $C$. utilis, $\mathrm{NAD}^{+}$-dependent isocitrate dehydrogenase activity was high even in the absence of AMP and did not significantly increase when AMP was present between 0.5 and $5 \mathrm{~mm}$ (Fig. $2 c$ ). In a cell-free extract dialysed against extraction buffer for $18 \mathrm{~h}$ to remove any endogenous AMP, the activity of the enzyme was not decreased and was still independent of exogenous AMP up to $2 \mathrm{mM}$ (results not shown). 

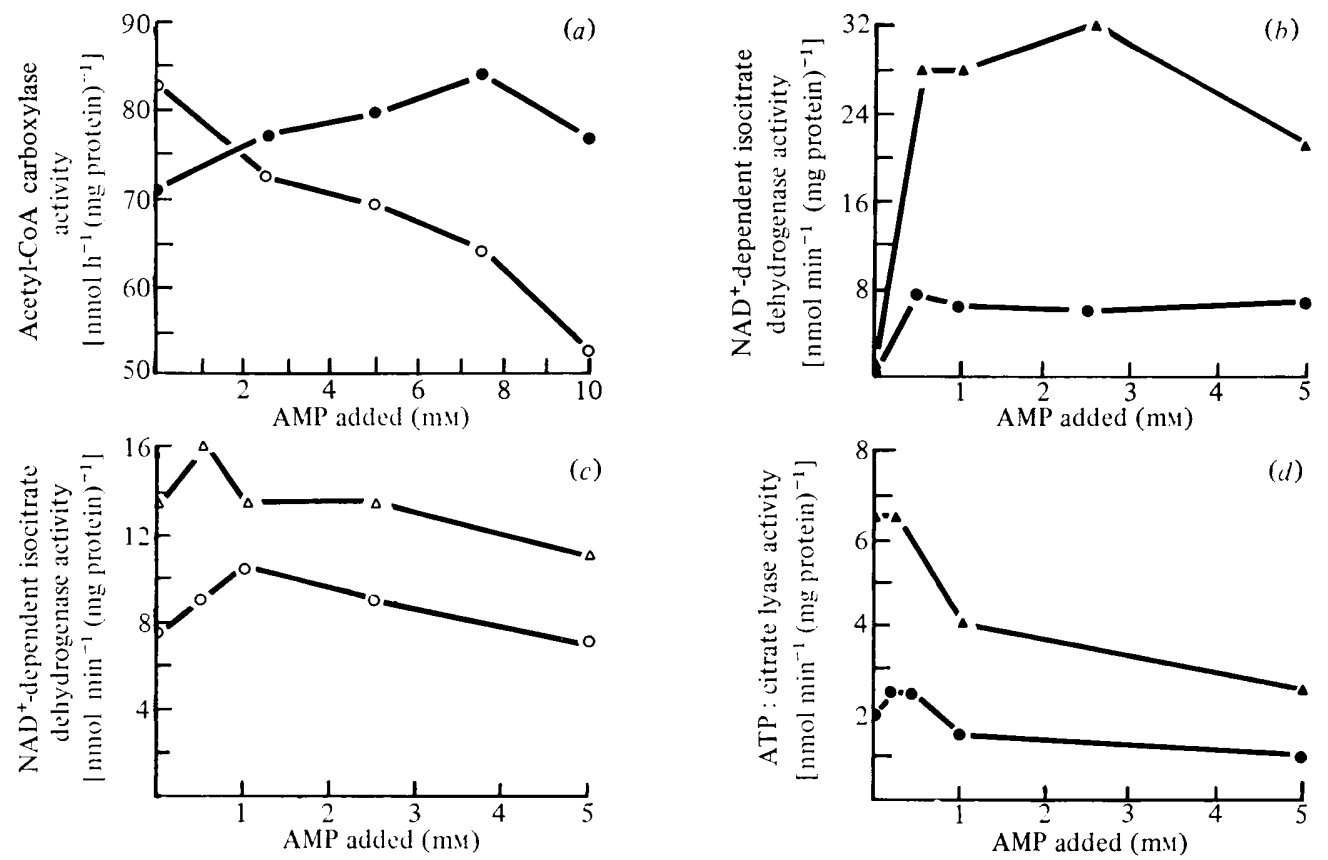

Fig. 2. Effect of physiological concentrations of AMP on the specific activities of various enzymes in cell-free extracts. (a) Acetyl-CoA carboxylase in Candida 107 (O) and C. utilis (O); extracts were prepared by ultrasonication of toluene-lysed cells grown in batch culture in carbon-limiting medium. (b) $\mathrm{NAD}^{+}$-dependent isocitrate dehydrogenase in Candida 107 grown in nitrogen-limiting (O) and carbon-limiting $(\boldsymbol{\Delta})$ medium; cells were grown in batch culture and disrupted ultrasonically. (c) $\mathrm{NAD}^{+}$-dependent isocitrate dehydrogenase in $C$. utilis grown in nitrogen-limiting $(O)$ and carbon-limiting $(\triangle)$ medium; cells were grown in batch culture and disrupted ultrasonically. $(d)$ ATP: citrate lyase in Candida 107 grown in nitrogen-limiting $(\mathbf{O})$ and carbon-limiting $(\mathbf{\Delta})$ medium; cells were grown in batch culture and disrupted ultrasonically.

Changes in the in vitro energy charge did not affect the enzyme activity in either Candida 107 or C. utilis (appropriate proportions of ATP, ADP and AMP were added but the total adenine nucleotide concentration was always maintained at $5 \mathrm{mM}$ ), except in Candida 107 at an energy charge of 1.0 when the complete absence of AMP led to almost total inactivity of the enzyme.

Thus, under conditions of lipid accumulation, $\mathrm{NAD}^{+}$-dependent isocitrate dehydrogenase would be inhibited in Candida 107 if the in vivo mitochondrial concentration of AMP was very low. We can only surmise that this is likely to be so as it is not yet possible to determine the amounts of adenine nucleotides in mitochondria with any degree of accuracy. ATP: citrate lyase. Mitochondrial citrate is probably the most important source of cytoplasmic acetyl-CoA (Srere, 1972). Citrate can cross the inner mitochondrial membrane where it can be cleaved by the enzyme ATP:citrate lyase to give oxaloacetate and acetylCoA, the precursor of fatty acid biosynthesis.

In extracts of both nitrogen- and carbon-limited cells of Candida 107, ATP: citrate lyase activity was low, which agreed with the findings of Whitworth \& Ratledge (1975) for Candida 107. AMP was partially inhibitory when added at $0.4 \mathrm{~mm}$ or greater (Fig. $2 d$ ).

Most significantly, however, the enzyme could not be detected in over 10 separately prepared extracts of $C$. utilis grown under either carbon- or nitrogen-limitation, with or without exogenous AMP added to the assay mixture. (The limit of detection of the assay system was about 60 pmol.) 
The effect of in vitro energy charge on the enzyme in Candida 107 was not investigated because its requirement for ATP involved the use of high, non-physiological concentrations of AMP to give low energy charges. However, with the high energy charge prevailing in nitrogen-limited cells of Candida 107, coupled with a low AMP concentration, the enzyme is unlikely to be inhibited during lipid accumulation.

Aconitase. Aconitase catalyses the reversible conversion of citrate to isocitrate via the intermediate cis-aconitate. It would therefore be responsible for the conversion of isocitrate to citrate following any build-up of isocitrate in the mitochondria.

The enzyme had about the same specific activity in both Candida 107 and C. utilis under

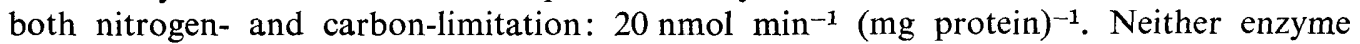
activity was modulated by AMP up to $2 \mathrm{mM}$ (results not shown).

$N A D^{+}$-dependent isocitrate dehydrogenase and ATP:citrate lyase in other micro-organisms

The essential differences between Candida 107 and $C$. utilis with respect to their enzyme activities related to lipid biosynthesis were the requirement of NAD ${ }^{+}$-dependent isocitrate dehydrogenase for AMP in Candida 107 and the absence of ATP:citrate lyase in C. utilis. If these two differences are the key to oleaginicity then other oleaginous micro-organisms should show the same characteristics as Candida 107. This proposition was examined in another species of yeast and in a species of mould. In each case two strains were used, one of which was oleagenic.

Rhodotorula glutinis. The lipid content of Rhodotorula glutinis strain NCYC 154G, growing in batch culture under conditions of nitrogen-limitation, is $50 \%$ of its dry weight, whereas strain NCYC 61 accumulates no more than $11 \%$ lipid (Hall, 1978).

$\mathrm{NAD}^{+}$-dependent isocitrate dehydrogenase in strain NCYC $154 \mathrm{G}$ was found to have an absolute requirement for AMP. AMP added to $0.2 \mathrm{mM}$ increased the specific activity from

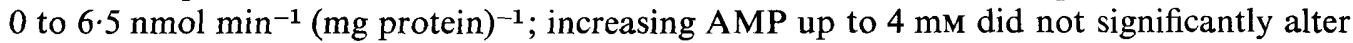
this specific activity (Fig. $3 a$ ). ATP:citrate lysase was present in this strain although at a low specific activity: $1.5 \mathrm{nmol} \mathrm{min}^{-1}$ (mg protein $)^{-1}$.

In strain NCYC 61, $\mathrm{NAD}^{+}$-dependent isocitrate dehydrogenase activity was high even in the absence of AMP and did not alter greatly in the presence of AMP between 0.2 and $4 \mathrm{mM}$ (Fig. $3 a$ ). ATP: citrate lyase was present (unlike the other non-oleaginous yeast,

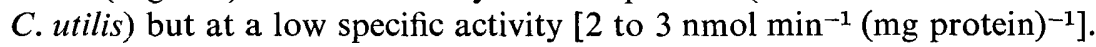

Mucor circinelloides. Mucor circinelloides strain CMI 31800 can accumulate up to $52 \%$ of its dry weight as lipid under nitrogen-limitation in batch culture (see Bernhauer \& Rauch, 1948); strain CMI 55452, however, contains no more than $14 \%$ lipid under the same growth conditions (C. Ratledge, unpublished results).

In the lipid-accumulating strain, the specific activity of $\mathrm{NAD}^{+}$-dependent isocitrate dehydrogenase was very low in the absence of AMP but increased ninefold when AMP was added at $0.2 \mathrm{mM}$. AMP up to $4 \mathrm{mM}$ was similarly effective in stimulating enzyme activity (Fig. $3 b$ ). ATP: citrate lyase was present in this strain at a specific activity of 8 to $9 \mathrm{nmol}$ $\min ^{-1}$ (mg protein) ${ }^{-1}$.

In the non-lipid-accumulating strain, CMI 55452, the specific activity of NAD+-dependent isocitrate dehydrogenase, though low in the absence of AMP, was still three times higher than the specific activity of the same enzyme in strain CMI 31800 under the same conditions. When 0.2 mM-AMP was added, the specific activity rose only twofold and did not significantly alter when AMP was increased up to $4 \mathrm{~mm}$ (Fig. $3 b$ ). ATP: citrate lyase was also present in this strain but at a lower specific activity than in the oleaginous strain [1 to $2 \mathrm{nmol} \min ^{-1}$ (mg protein) $)^{-1}$.

If the energy charges and AMP concentrations in these two pairs of organisms follow the same patterns as previously seen in Candida 107 and C. utilis, the NAD+-dependent isocitrate dehydrogenase in the two oleaginous strains ( $R$. glutinis NCYC $154 \mathrm{G}$ and M. circinel- 


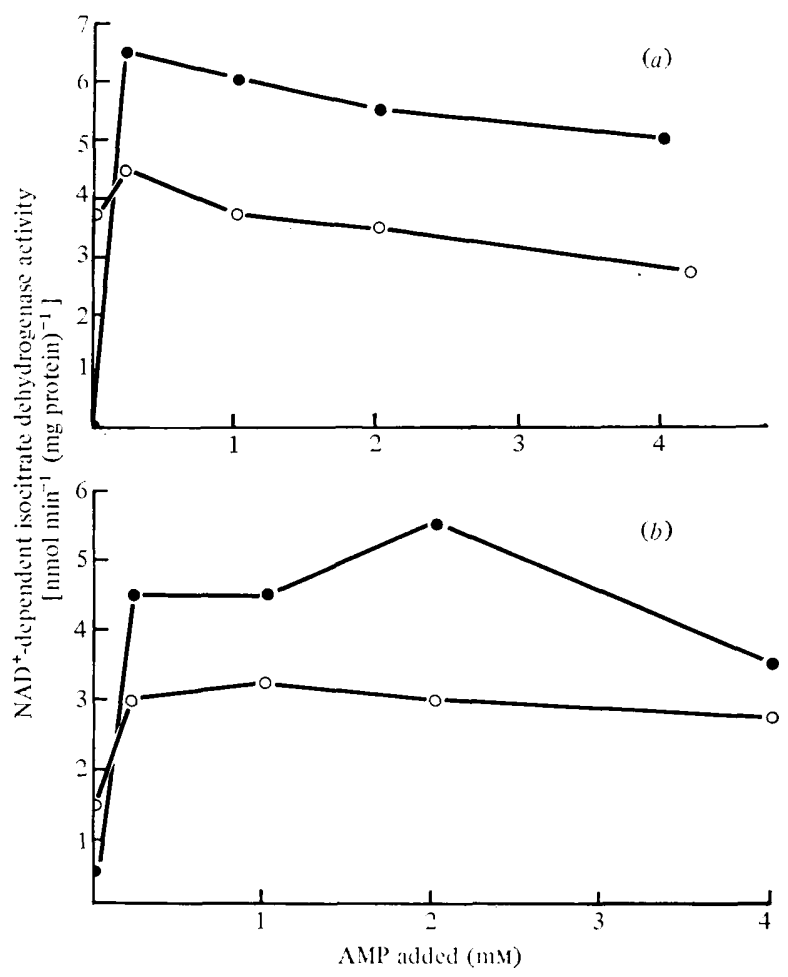

Fig. 3. Effect of physiological concentrations of AMP on the specific activity of NAD ${ }^{+}$-dependent isocitrate dehydrogenase in cell-free extracts of $(a)$ Rhodotorula glutinis strains NCYC 154G (lipid-accumulating) (O) and NCYC $61(O)$ and (b) Mucor circinelloides strains CMI 31800 (lipid accumulating) $(O)$ and $C M I 55452(\bigcirc)$. Cells were grown under nitrogen-limitation in batch culture and disrupted ultrasonically.

loides CMI 31800) would become inactive during nitrogen-limited growth. The accumulating isocitrate and citrate would then be cleaved to provide the necessary supply of acetyl-CoA for lipid biosynthesis. In the non-oleaginous organisms the activities of the two enzymes, being similar to those found in C. utilis, would explain the failure of these strains to accumulate lipid.

\section{HYPOTHESIS FOR LIPID ACCUMULATION}

Lipid accumulation depends upon several events occurring but is not necessarily caused by them. For example, neither glucose transport nor fatty acid biosynthesis must be repressed or inhibited; nor must the lipid which is synthesized be degraded. As these conditions are satisfied both in the oleaginous yeast Candida 107 and in C. utilis, the reason for lipid accumulation must lie elsewhere.

The key to oleaginicity, we believe, lies in the build-up of ATP and the depletion of AMP in cells whose growth is limited by the supply of nitrogen (or presumably any other nutrient besides carbon). We assume that the concentrations of nucleotides within the mitochondria are similar to, or even more extreme than, those measured in the total intracellular contents. The depletion of AMP in nitrogen-limited cells leads to an inactivation of mitochondrial $\mathrm{NAD}^{+}$-dependent isocitrate dehydrogenase. Similar observations made in Candida lipolytica may account for the accumulation of citrate (Marchal et al., 1977). The isocitrate which accumulates will equilibrate to citrate via aconitase which is unaffected by changes in energy charge. The citrate will be transported out of the mitochondrion and cleaved by ATP: citrate 
MITOCHONDRION

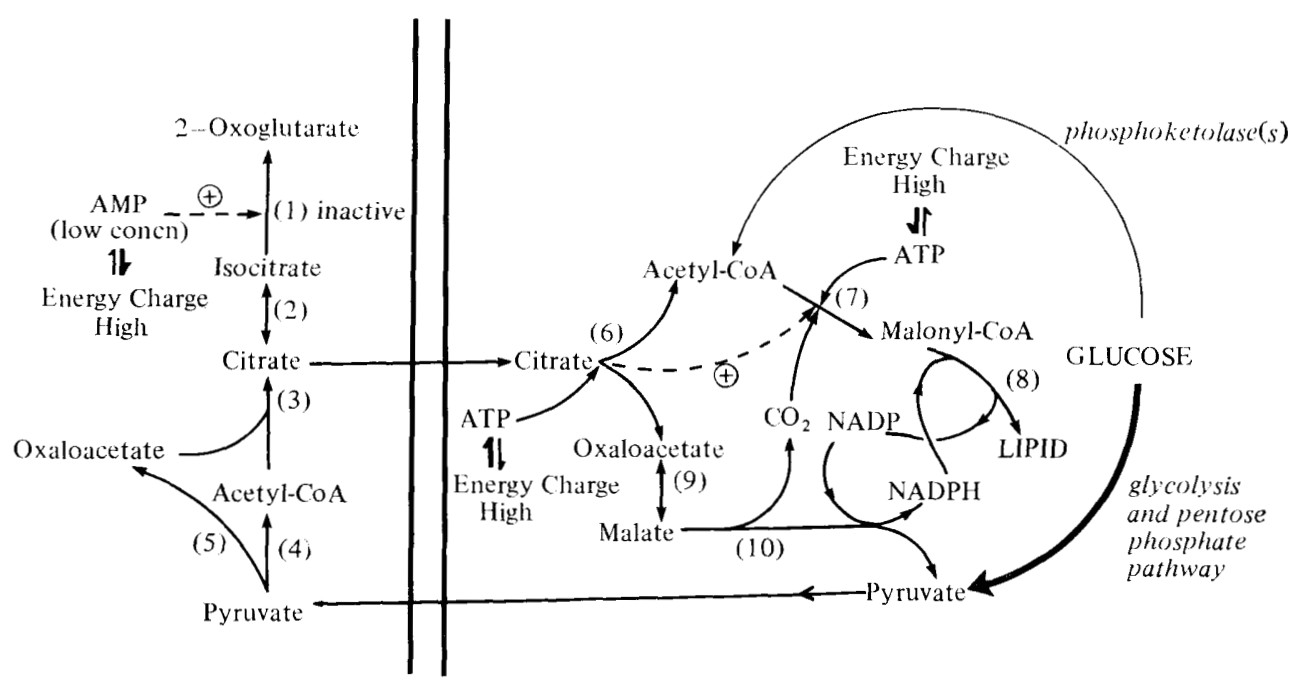

Fig. 4. Diagrammatic representation of the flow of carbon from glucose into lipid in Candida 107 during the process of lipid accumulation. Phosphoketolases are present in this yeast but are probably responsible for only a minor amount of acetyl-CoA synthesis; the principal flow of carbon is shown by the heavier lines.

Enzymes: 1, $\mathrm{NAD}^{+}$-dependent isocitrate dehydrogenase; 2, aconitase; 3, citrate synthase; 4 , pyruvate dehydrogenase; 5, pyruvate carboxylase; 6 , ATP: citrate lyase; 7, acetyl-CoA carboxylase; 8, fatty acid synthetase; 9, malate dehydrogenase; 10, malic enzyme. Effectors of enzymes shown: $\oplus$.

Energy charge (Atkinson, 1969) during lipid accumulation is in favour of ATP formation.

lyase into oxaloacetate and acetyl-CoA. [Some minor supplementation of acetyl-CoA may occur in Candida 107 by the action of phosphoketolases on hexose and pentose phosphates (Whitworth \& Ratledge, 1977; Ratledge \& Botham, 1977).] The acetyl-CoA is then available for fatty acid biosynthesis, with acetyl-CoA carboxylase, the regulatory enzyme of this pathway, being stimulated by citrate. This phenomenon is well-described for mammalian systems (Lane et al., 1974; Vagelos, 1974) though it may be less important in vivo than in vitro experiments suggest (Volpe \& Vagelos, 1976). The enzyme from Candida 107 is distinct from that from $C$. utilis in being activated in vitro by citrate. The extent of this activation in vivo is as yet unknown.

Neither ATP: citrate lyase nor acetyl-CoA carboxylase will be depleted of ATP as a cosubstrate when the energy charge is high. The oxaloacetate arising from citrate cleavage will probably be converted to malate and then decarboxylated to pyruvate. The former reaction is catalysed by malate dehydrogenase which is highly active in Candida 107 (Whitworth \& Ratledge, 1975). The latter reaction is catalysed by malic enzyme which is also present in this yeast (Whitworth \& Ratledge, 1975) and which, moreover, will produce $\mathrm{CO}_{2}$ and NADPH. The $\mathrm{CO}_{2}$ will be used, amongst other reactions, by the acetyl-CoA carboxylase and the NADPH will be used by the fatty acid synthetase. NADPH can, of course, also be produced by the pentose phosphate cycle through which up to $65 \%$ of the carbon of glucose is metabolized (Ratledge \& Botham, 1977). The pyruvate derived from the malate will enter the mitochondrion to be dissimilated into acetyl-CoA and oxaloacetate; the subsequent synthesis of citrate, via citrate synthase, is not unduly affected by a high energy charge (C. A. Boulton \& C. Ratledge, unpublished work).

The sequence of events leading to lipid synthesis is outlined in the scheme shown in Fig. 4. 
The scheme assumes the location of some enzymes. For example, pyruvate carboxylase (enzyme 5 in scheme) might be in the cytoplasm as in baker's yeast (Haarasilta \& Taskinen, 1977) though we have shown it in the mitochondrion which is its location in animal cells. There may be additional controls not examined in this work. Pyruvate carboxylase, for example, increases in activity with increasing energy charge (Miller \& Atkinson, 1972). Translocation of acids across the mitochondrial membrane is more complex than shown in the scheme and may also be a controllable process (Lowenstein, 1971; Briquet, 1977). A somewhat similar sequence of events possibly occurs in animal cells (Markall \& Lane, 1977).

The same events are inferred to occur in the oleaginous strains of Rhodotorula glutinis and Mucor circinelloides which were also studied here. These strains also contain an AMPrequiring, $\mathrm{NAD}^{+}$-dependent isocitrate dehydrogenase and an ATP:citrate lyase. In C. utilis neither of these two key activities is present. In the non-oleaginous strains of $R$. glutinis and $M$. circinelloides, though ATP: citrate lyase was present, $\mathrm{NAD}^{+}$-dependent isocitrate dehydrogenase was active in the absence of AMP. Hence, production of acetyl-CoA in these strains would be limited for the reasons advanced above.

Lipid accumulation therefore results from the concerted action of several enzymes and metabolic activities. Our observations appear to fit in with more general theories currently being advanced to explain the accumulation of other reserve materials, such as glycogen and polyphosphates, in terms of the prevailing concentrations of adenine nucleotides within the microbial cell (Chapman \& Atkinson, 1977; Knowles, 1977).

P. A. Botham was supported by an SRC research studentship. We thank M. J. Hall and A. R. J. Smith for some technical assistance with chemostat cultivation of microorganisms.

\section{REFERENCES}

Anfinsen, C. B. (1955). Aconitase from pig heart muscle. Methods in Enzymology 1, 695-698.

Atkinson, D. E. (1969). Regulation of enzyme function. Annual Review of Microbiology 23, 47-68.

AtKinson, D. E. (1977). Cellular Energy Metabolism and its Regulation. New York, San Francisco \& London: Academic Press.

BabiJ, T., Moss, F. J. \& RaLPH, B. J. (1969). Effects of oxygen and glucose levels on lipid composition of the yeast Candida utilis growing in continuous culture. Biotechnology and Bioengineering 11, 593-603.

Bernhauer, K. \& RaUCH, J. (1948). Beitrage zur mikrobiologischen Eiweiss- und Fettsynthese. I. Die grundlegenden Bedingungen für die Eiweiss und Fett Produktion durch Mycelpilze in der Submers-Kultur. Biochemische Zeitschrift 319, 77-93.

Botham, P. A. \& Ratledge, C. (1978). Metabolic studies related to lipid accumulation in yeast. Biochemical Society Transactions 6, 383-385.

BRIQUET, M. (1977). Transport of pyruvate and lactate in yeast mitochondria. Biochimica et biophysica acta 459, 290-299.

Chapman, A. G. \& Atkinson, D. E. (1977). Adenine nucleotide concentrations and turnover rates. Their correlation with biological activity in bacteria and yeast. Advances in Microbial Physio$\log y 15,253-306$.
Chapman, A. G., Fall, L. \& Atkinson, D. E. (1971). Adenylate energy charge in Escherichia coli during growth and starvation. Journal of Bacteriology 108, 1072-1086.

Chapman, C. \& Bartley, W. (1969). Adenosine phosphates and the control of glycolysis and gluconeogenesis in yeast. Biochemical Journal 111, 609-613.

Dawes, E. A. \& Large, P. J. (1970). Effect of starvation on the viability and cellular constituents of Zymomonas anaerobia and Zymomonas mobilis. Journal of General Microbiology 60, 31-42.

Dolezal, J. \& KapraleK, F. (1976). Physiological characteristics of chemostatically grown Citrobacter freundii as a function of specific growth rate and type of nutrient limitation. Folia microbiologica 21, 168-177.

Gill, C. O. \& Ratledge, C. (1973a). Inhibition of glucose assimilation and transport by $n$-decane and other $n$-alkanes in Candida 107. Journal of General Microbiology 75, 11-22.

Gill, C. O. \& RAtLedge, C. (1973b). Regulation of de novo fatty acid biosynthesis in the $n$-alkane utilizing yeast, Candida 107. Journal of General Microbiology 78, 337-347.

Gill, C. O., Hall, M. J. \& Ratledge, C. (1977). Lipid accumulation in an oleaginous yeast, Candida 107, growing on glucose in single-stage continuous culture. Applied and Environmental Microbiology 33, 231-239. 
Gornall, A. G., Bardawill, C. J. \& David, M. M. (1949). Determination of serum proteins by means of the biuret reaction. Journal of Biological Chemistry 177, 751-766.

HaARasilta, S. \& TASKINEN, L. (1977). Location of three key enzymes of gluconeogenesis in baker's yeast. Archives of Microbiology 113, 159-161.

HALL, M. J. (1978). Growth of oleaginous yeasts in continuous culture. M.Sc. Thesis, University of Hull.

Harrison, D. E. F. \& Maitra, P. K. (1969). Control of respiration and metabolism in growing Klebsiella aerogenes. The role of adenine nucleotides. Biochemical Journal 112, 123-134.

Hathaway, J. A. \& Atkinson, D. E. (1963). The effect of adenylic acid on yeast nicotinamide adenine dinucleotide isocitrate dehydrogenase, a possible metabolic control mechanism. Journal of Biological Chemistry 238, 2875-2881.

Hayashi, E., Hasegawa, R. \& Tomita, T. (1978). The fluctuation of various enzyme activities due to myoinositol deficiency in Saccharomyces cerevisiae. Biochimica et biophysica acta 540, 231-237.

Hobson, P. N. \& Summers, R. (1972). ATP pool and growth yield in Selenomonas ruminantium. Journal of General Microbiology 70, 351-360.

Höfer, M., Becker, J.-U., Brand, K., Deckner, K. \& BETZ, A. (1969). A study of the enzyme equipment of the yeast Rhodotorula gracilis. FEBS Letters 3, 322-324.

InOue, H. \& Lowenstein, J. M. (1975). Acetylcoenzyme A carboxylase from rat liver. Methods in Enzymology 35, 3-11.

Kessell, R. H. J. (1968). Fatty acids of Rhodotorula gracilis: fat production in submerged culture and the particular effect of $\mathrm{pH}$ value. Journal of Applied Bacteriology 31, 220-231.

KNOWLES, C. J. (1977). Microbial metabolic regulation by adenine nucleotide pools. Symposia of the Society for General Microbiology 27, 241-283.

KorNBerG, A. (1955). Isocitric dehydrogenase of yeast. Methods in Enzymology 1, 705-709.

Kornberg, A. \& Pricer, W. E. (1951). Di- and triphosphopyridine nucleotide isocitrate dehydrogenases in yeast. Journal of Biological Chemistry 189, 123-136.

Lane, M. D., Moss, J. \& Polakis, S. E. (1974). Acetyl-coenzyme A carboxylase. Current Topics in Cellular Regulation 8, 139-195.

Lowenstein, J. M. (1971). The pyruvate dehydrogenase complex and the citric acid cycle. In Comprehensive Biochemistry, vol. 18S, pp. 1-55. Edited by M. Florkin \& E. H. Stotz. Amsterdam, London \& New York: Elsevier.

Marchal, R., Vandecasteele, J. P. \& Metche, M. (1977). Regulation of the central metabolism in relation to citric acid production in Saccharomycopsis lipolytica. Archives of Microbiology 113, 99-104.

MarKall, J. C. \& Lane, M. D. (1977). Role of pyruvate carboxylase in fatty acid synthesis: alterations during preadipocyte differentiations. Biochemical and Biophysical Research Communications 79, 720-725.

Matsuhashi, M. (1969). Acetyl-coenzyme A carboxylase from yeast. Methods in Enzymology 14, 3-8.
Miller, A. L. \& Atkinson, D. E. (1972). Response of yeast pyruvate carboxylase to the adenylate energy charge and other regulatory parameters. Archives of Biochemistry and Biophysics 152, 531-538.

Mitsushima, K., Shinmyo, A. \& Enatsu, T. (1978). Control of citrate and 2-oxoglutarate formation in Candida lipolytica mitochondria by adenine nucleotides. Biochimica et biophysica acta 538, $481-492$.

Neijssel, O. M., Hueting, S. \& Tempest, D. W. (1977). Glucose transport capacity is not the ratelimiting step in the growth of some wild-type strains of Escherichia coli and Klebsiella aerogenes. FEMS Microbiology Letters 2, 1-3.

Rasmussen, P. K. \& KLEIN, H. P. (1967). Regulation of acetyl-CoA carboxylase of Saccharomyces cerevisiae. Biochemical and Biophysical Research Communications 28, 415-419.

Rasmussen, P. K. \& KLeIN, H. P. (1968). Activation of fatty acid synthesis in cell-free extracts of Saccharomyces cerevisiae. Journal of Bacteriology 95, 157-161.

RATLEDGe, C. (1978). Lipids and fatty acids. In Economic Microbiology, vol. 2, pp. 263-301. Edited by A. H. Rose. New York \& London: Academic Press.

Ratledge, C. \& Botham, P. A. (1977). Pathways of glucose metabolism in Candida 107, a lipidaccumulating yeast. Journal of General Microbiology 102, 391-395.

Rattray, J. B. M., Schibeci, A. \& Kidby, D. K. (1975). Lipids of yeasts. Bacteriological Reviews 39, 197-231.

Rouser, G., Kritchevsky, G. \& Yamamoto, A. (1967). Column chromatographic and associated procedures for separation and determination of phosphatides and glycolipids. In Lipid Chromatographic Analysis, pp. 99-162. Edited by G. W. Marsetti. London: Edward Arnold.

Serrano, R., Gancedo, J. M. \& Gancedo, C. (1973). Assay of yeast enzymes in situ. A potential tool in regulation studies. European Journal of Biochemistry 34, 479-482.

Simon, E. J. \& Shemin, D. (1953). Synthesis of acetyl-CoA. Journal of the American Chemical Society 75, 2520.

Sols, A., Gancedo, C. \& Delafuente, G. (1971). Energy-yielding metabolism in yeasts. In The Yeasts, vol. 2, pp. 271-308. Edited by A. H. Rose. New York \& London: Academic Press.

SRERE, P. A. (1962). Citrate-cleavage enzyme. Methods in Enzymology 5, 641-644.

Srere, P. A. (1972). The citrate enzymes: their structures, mechanisms and biological functions. Current Topics in Cellular Regulation 5, 229 283.

Strehler, B. L. \& McElroy, W. D. (1957). Assay of adenosine triphosphate. Methods in Enzymo$\log y 3,871-873$.

Thomas, K. C. \& Dawson, P.S. S. (1977). Variations in the adenylate energy charge during phased growth (cell cycle) of Candida utilis under energy excess and energy-limiting growth conditions. Journal of Bacteriology 132, 36-43.

THORPE, R. F. \& RATLEDGe, C. (1972). Fatty acid distribution in triglycerides of yeasts grown on 
glucose or $n$-alkanes. Journal of General Microbiology 72, 151-163.

Uzuka, Y., Kanamori, T., Koga, T., Tanaka, K. \& Nagauma, T. (1975). Isolation and chemical composition of intracellular oil globules from the yeast Lipomyces starkeyi. Journal of General and Applied Microbiology 21, 157-168.

VAGELOS, P. R. (1974). Biosynthesis of saturated fatty acids. In MTP International Review of Science: Biochemistry (Series One), vol. 4, Biochemistry of Lipids, pp. 99-140. Edited by T. W. Goodwin. London: Butterworths.

VolPE, J. J. \& VAGelos, P. R. (1976). Biosynthesis of fatty acids. Physiological Reviews 56, 339-417.

WEBSTER, L. T. (1969). Acetyl-CoA carboxylase. Methods in Enzymology 13, 375-381.
White, D. \& KLeiN, H. P. (1965). Factors affecting fatty acid synthesis in cell-free preparations from Saccharomyces cerevisiae. Biochemical and Biophysical Research Communications 20, 78-84.

WhITE, D. \& KIEIN, H. P. (1966). Effects of $\alpha$-glycerophosphate and of palmitoyl-coenzyme A on lipid synthesis in yeast extracts. Journal of Bacteriology 91, 1218-1223.

Whitworth, D. A. \& Ratledge, C. (1975). An analysis of intermediary metabolism and its control in a fat-synthesizing yeast (Candida 107) growing on glucose or alkanes. Journal of General Microbiology 88, 275-288.

Whitworth, D. A. \& Ratledge, C. (1977). Phosphoketolase in Rhodotorula graminis and other yeasts. Journal of General Microbiology 102, 397-401. 